\title{
Educational Practitioners on Professional Community and Sense of Community
}

\author{
Adela Elena Popa ${ }^{*}$ \\ ${ }^{1}$ Lucian Blaga University of Sibiu, Department of Sociology and Social Work, 2-4 Lucian Blaga, 550169 Sibiu, Romania
}

KEYWORDS

Preschool education

Professional community

Professional group

Sense of community
ABSTRACT

The study aims to address two areas regarding preschool education: the participation of preschool practitioners in professional groups and communities and the views and understandings they hold on the 'professional community' concept. A survey was completed by teachers and specialists working with preschool children in all kindergartens of Sibiu ( $\mathrm{N=308)}$ in July 2011. A quantitative and qualitative approach of the data was used, for processing a part of the survey's items. Results show a high participation of practitioners in professional groups within their own institution, but less implication in national or international groups and communities. The respondents' views on professional community show a basic understanding of it, as a place for interaction and communication in order to get support and advice when needed. Several practical implications are drawn after discussing the results.

\section{Introduction}

The professional communities functioning in different work fields represent a subject intensely studied in the last years. The theme was generously addressed in education, based on the assumption that a professional community of teachers and/or specialists working with children at different ages can contribute to improving several aspects related to: teaching activity, students' performance and overall success of the school activities (see the next section).

\footnotetext{
* Contact address: adela.popa@ulbsibiu.ro (A.E. Popa)
} 
Many researches showed that performance in education of all the stakeholders involved is increased by a more supportive work environment, and one way to assure this can be a professional community for teachers and other professionals to be involved in. The hereby article addresses the problem of the potential professional community of teachers/specialists working with preschool children in Sibiu city. A research collecting quantitative and qualitative data (focus-groups and survey) was undertaken between November 2010 and July 2011. Results from the qualitative inquiry are forthcoming (Baranowska, McGillivray and Popa 2011; Popa 2011). The survey focused on issues related to the professional groups the teachers and specialists in kindergartens belong (see Methods section). This article will analyse the questions related to professional community in this survey. Thus, we hope to add some significant knowledge on the debate regarding professional communities, their role, features and potential benefits.

The main goal of our analysis is to identify what are the views of kindergarten teachers and specialists on professional community as a context for their work. We consider this to be of significant importance as we presume that teachers will put into practice a professional community according to their views and understandings on how it should be. In order to achieve this a few questions will guide the present analysis: i) What are the characteristics of the professional groups in which the respondents belong (type, size)? ii) Do they consider the professional groups they belong to as professional communities? iii) Are they satisfied with these groups/communities they belong? iv) What are the subjects' understandings of professional community in general?

\section{Theoretical Framework}

The socio-constructivist paradigm is more and more employed in the educational milieu in order both to explain how learning and participation are achieved, and to foster specific practices (Levine, Laufgraben and Shapiro 2004). The same paradigm informs the present study approach to professional community among teachers in preschool educational institutions. It stresses the active implication of teachers in their work and professional relations, as well as the interactional nature of the educational 
activities. For this reason, the socio-constructivist approach can also be used for understanding the professional community of teachers, although, in the scientific literature, it is mainly used for explaining the learning communities among students.

Four concepts are relevant for data in our study: professional group (Evetts 2006), community (Cohen 1985), professional community (Kruse, Louis and Bryk 1995) and sense of community (McMillan and Chavis 1986). We will address them in the next paragraphs. First, we will draw the analysis on the 'community' concept as defined by Cohen (1985: 12): a group of people whose members 'have something in common with each other which distinguishes them in a significant way from the members of other putative groups'. The section on analysis and results will show that the most frequent significance of 'community' for our subjects is related to those things the community members share.

Second, our research will use the concept of 'professional group', which has gained a great visibility in the last years. While, for several years, the contributions endeavoured to define the 'profession' concept, nowadays the interest has shifted on professional groups (Bourgeault, Benoit and Hirschkorn 2009), more often using a comparative approach. The most frequent understanding of the term 'professional group' is a social group within a profession, which can greatly vary in size, occupation field, goals, etc. (Evetts 2006).

The difficulties regarding the 'professional community' concept pertain both to the definition and the operationalization. Lomos, Hofman and Bosker (2011) present a careful meta-analysis of the concept definition in the context of student achievement. Different theoretical perspectives and many empirical evidences concur to the definition of the concept, making it difficult to grasp. Additionally, the construct has had a long history and evolution since it was proposed in the literature, thirty years ago. Also, the fact that the concept is used in many contexts, turns it into a fuzzy notion (Visscher and Witziers 2004). For the use of our analysis, we will use one of the definitions in literature, proposed by Kruse, Louis and Bryk (1995: 36). Professional community consists in 'shared values, reflective dialogue, deprivatization of practice, focus on student learning and collaboration among teachers'. The authors also propose an operationalization of the 
professional community concept, using three dimensions: characteristics, structural conditions, and human and social resources. We will ground the data analysis in the present study on this framework (see Analysis section).

Another broad discussion within this topic, relevant for our study, regards the benefits brought by a functional professional community. Being a member in such a community can increase responsibility of teachers, personal commitment to work and effectiveness. Kruse, Louis and Bryk (1995) conclude that empowerment, sense of satisfaction with dignity of work and greater collective responsibility for students learning are the main positive outcomes deriving from membership in a professional community. Other authors (Walker, Wasserman and Wellman, 1994; Wellman and Gulia, 1999) add a greater sense of well being and opportunities for support, as other outcomes.

A very rich literature informs the debate regarding the fourth concept relevant for our analysis, i.e. the sense of community. The definition of the last one, given by McMillan and Chavis (1986: 9), is: a 'feeling that members have of belonging, a feeling that members matter to one another and to the group, and a shared faith that members' needs will be met through their commitment to be together'. Starting from this definition, the authors present four elements as the foundation of the sense of community: membership, influence, integration and fulfilment of needs and shared emotional connection. We will draw the discussion of our results on these four elements.

Other elements are also considered essential for the existence of a sense of community among members: similar interests and common goals (Westheimer and Kahne 1993), cohesive interaction, respect for individual differences and reflection on work of the group (Graves 1992). Rovai (2002) adds mutual interdependence and overlapping histories among members, connectedness, spirit, trust and common expectations.

Apart from the general approaches of the sense of community concept, numerous uses are also proposed for the educational field. Just to mention a few, the term is employed by Dawson (2006) in relation to the student communication and by Rovai (2002), who developed a scale to measure sense of community within the classroom. The concept is also employed with reference to the school psychologists interactions (Kruger et al. 2001), to 
the effects of computer use on the sense of community of high school pupils (Wighting 2006), or in relation to a particular type of university (Ferrari et al. 2009). More specific to our paper, there are studies focusing on preschool teachers' sense of community (McGinty, Justice and Rimm-Kaufman 2008; Guo et al. 2011). Two dimensions are considered important in the study of the teachers' sense of community: teacher collegiality (the collaboration among teachers) and teacher influence (in relation to the administrative decision making) (McGinty, Justice and Rimm-Kaufman 2008: 363). The same study emphasizes career affirmation, professional growth and feelings of reward in teaching as potential benefits of a strong sense of community in teacher's ethos.

\section{Methods and Participants}

The objectives for the survey research were first to assess if teachers/specialists working with preschool children in kindergartens are members in professional groups and to explore the features of these groups. Second, we aimed to understand how these professional groups were functioning, by focusing on membership characteristics, communication channels, pattern and frequency of interaction, norms and regulations. Third, we were interested in seeing if practitioners understand the groups they belonged to as professional communities and also to grasp their understandings of such a community.

The survey was conducted in July 2011 in all the 17 kindergartens of Sibiu city area. The target population consisted in two broad categories of practitioners working with children: (1) teachers in kindergartens and (2) other types of educational and psychological professionals, such as: school psychologists, speech therapists, support teachers and psychological pedagogues. A total of 263 teachers and 96 practitioners in the second category work in kindergartens in Sibiu. Our survey targeted nearly all the population in the first category and half of the population in the second category. As a result, 258 kindergarten teachers and 50 specialists completed the survey, assuring a rate of response of $98.09 \%$ and $52.08 \%$ respectively. The mean age of the participants was 37.43 years $(S . D=12.1)$ and females represented $97.7 \%$ of the sample. 


\section{Analysis and Results}

For answering the research questions, several items in the survey were analysed. Most of them were explored descriptively (see table 1), whereas the question regarding the subjects' understandings on 'professional community' was qualitatively analysed. The close-ended items were analysed descriptively in order to briefly present the context of belonging in professional groups. The bulk of the present analysis will focus on the openended question, which was processed using a qualitative approach.

\section{Belonging to professional groups - descriptive exploration}

Several items describe the belonging of our respondents in different professional groups. To assure a common understanding on the 'professional group' concept among our participants, a definition was given at the beginning of the survey: any type of partnership between practitioners in the same field of work, more or less formal, with the goal of offering support, guiding and exchange of ideas and resources to its members. Results of the items analysed can be seen in Table 1. Given the fact that the survey was completed by almost all preschool practitioners in Sibiu city, the results are very meaningful.

Certainly one positive finding is that there is massive participation of preschool teachers and specialists in at least one professional group. One can observe a more intense participation in institutional professional groups, and less in local or national groups. Regarding the size of the group, the results show a rather narrow social participation, confined to middle-sized groups of teachers. Participation in large groups, with more than 30 members is characteristic for just a small percentage in the sample. When asked whether the most active professional group in which they currently belong can be considered a professional community, a broad consensus was achieved as almost all respondents have answered affirmatively. Also respondents have rated highly positively their satisfaction regarding this group/community in which they belong. 
A.E. Popa - Educational Practitioners on Professional Community and Sense of Community

Table 1. Preschool practitioners' belonging in professional groups (PG)

\begin{tabular}{|c|c|c|c|c|c|}
\hline No. & Question & Measurement & & Answers & \\
\hline \multirow[t]{2}{*}{1} & \multirow[t]{2}{*}{$\begin{array}{l}\text { Do you belong } \\
\text { to one or more } \\
\text { than one PGs? }\end{array}$} & \multirow[t]{2}{*}{$\begin{array}{l}\text { Dichotomous } \\
\text { question } \\
\text { (nominal) }\end{array}$} & \multicolumn{3}{|c|}{$\begin{array}{l}54.2 \% \text {-- one group } \\
37.7 \% \text {-- more than one group }\end{array}$} \\
\hline & & & $\begin{array}{l}\text { First choice } \\
(92 \% \text { of } N=308)\end{array}$ & $\begin{array}{l}\text { Second choice }(56 \% \\
\text { of } N=308)\end{array}$ & $\begin{array}{l}\text { Third choice }(32 \% \\
\text { of } N=308)\end{array}$ \\
\hline 2 & $\begin{array}{l}\text { In what PG do } \\
\text { you belong? }\end{array}$ & $\begin{array}{l}\text { Close-ended } \\
\text { question } \\
\text { (nominal) }\end{array}$ & $\begin{array}{l}80.2 \% \text { - PG } \\
\text { within the } \\
\text { institution } \\
12 \% \text { - PG } \\
\text { outside the } \\
\text { institution (local } \\
\text { or national) }\end{array}$ & $\begin{array}{l}30.8 \% \text { - PG within } \\
\text { the institution } \\
25.7 \% \text { - PG outside } \\
\text { the institution (local } \\
\text { or national) }\end{array}$ & $\begin{array}{l}4.5 \% \text { - PG within } \\
\text { the institution } \\
84.7 \% \text { - PG outside } \\
\text { the institution } \\
\text { (local or national) }\end{array}$ \\
\hline 3 & $\begin{array}{l}\text { How many } \\
\text { members are } \\
\text { in the PG you } \\
\text { currently } \\
\text { belong to?* }\end{array}$ & $\begin{array}{l}\text { Close-ended } \\
\text { question } \\
\text { (ordinal) }\end{array}$ & $\begin{array}{l}\text { 11-20 members - } \\
21-30 \text { members - } \\
5-10 \text { members - } \\
31-50 \text { members - } \\
51-100 \text { members } \\
\text { Less than } 5 \text { mem } \\
\text { More than } 100 \mathrm{~m}\end{array}$ & $\begin{array}{l}1.4 \% \\
7.3 \% \\
3 \% \\
7 \% \\
5.2 \% \\
\text { rs }-4.9 \% \\
\text { nbers }-3.6 \%\end{array}$ & \\
\hline 4 & $\begin{array}{l}\text { Can this group } \\
\text { in which you } \\
\text { belong be } \\
\text { considered as } \\
\text { a professional } \\
\text { community?* }\end{array}$ & $\begin{array}{l}\text { Dichotomous } \\
\text { question } \\
\text { (nominal) }\end{array}$ & $\begin{array}{l}89.6 \%-- \text { Yes } \\
8.1 \%-- \text { No }\end{array}$ & & \\
\hline 5 & $\begin{array}{l}\text { Generally } \\
\text { speaking, how } \\
\text { satisfied are } \\
\text { you with the } \\
\text { overall activity } \\
\text { of this group?* }\end{array}$ & $\begin{array}{l}\text { Close-ended } \\
\text { question } \\
\text { (ordinal, } \\
\text { Likert scale) }\end{array}$ & $\begin{array}{l}\text { Very satisfied an } \\
\text { Neither satisfied, } \\
\text { Unsatisfied and }\end{array}$ & $\begin{array}{l}\text { satisfied - } 81.5 \% \\
\text { or unsatisfied - } 16.2 \% \\
\text { cy unsatisfied }-1.0 \%\end{array}$ & \\
\hline
\end{tabular}

* Before asking these questions, respondents were asked to choose the professional group in which they participate more intensely, if they are members in more than one group.

\section{Understandings of 'professional community' concept - qualitative analysis}

Apart from the items quantitatively analysed above, a careful attention was given to the open-ended question 'What do you understand by 'professional community' in general?' The answers received here $(n=181)$ were openly coded in order to grasp the respondents' understandings of the professional community construct. The great variety of definitions given to this concept in the scientific literature is also found in our data as the survey responses on this question showed many different understandings on professional community. To put an order into these understandings and to interpret 
them according to what is found in the literature on this theme, proved to be a challenging task.

First, the most part of the accounts equated the professional community with a 'network' of people interacting together based on common interests; three accounts consider the professional community as a 'team', just one spokes about 'family' and another one about 'association'. Beck (1999: 19) explores the metaphors used for explaining the 'community' concept in the educational context and concludes that the 'family' metaphor is widely used in the contemporary educational research for conveying the important meanings of the concept. Other metaphors identified by Beck such as village or orchestra, are not present in our research. Attempting to define professional community, there were occurrences that made reference to one's own group (e.g. 'the group of teachers in which I belong, in the kindergarten where I work'). Such answers illustrate a sense of we-ness that exists among teachers and specialists.

Table 2. Elements shared by members of a professional community (descending order)

Professional community represents a group of people that have the same...

Goals
Interests
Preoccupations
Work field
Ideas and opinions
Professional training
Norms and regulations
Aspirations/ideals
Localization
Values
Habits
Certain features
Needs
Skills
Language

Drawing on the Cohen's definition mentioned above, we have explored the accounts defining community as a social group whose members share something. Nearly all accounts used this definition and a 
very wide range of shared elements were mentioned (Table 2). Goals and interests are the most invoked, whereas elements frequently mentioned in the literature - such as values and needs - are less brought up by our subjects.

The framework for analysing the professional community in the educational field proves to be a useful tool for understanding and conceptualising the construct. The next step in analysing the data in the present study was to assess in what extent the responses in our study are concurrent with this framework. Several features within the three dimensions are found in our study, others are completely missing and others are present but in a slightly different way (see Table 3). Where there are overlapping features in the framework in our analysis, a relevant quote is given for the overlapping features. At the first glance, there are missing features in all three dimensions. Almost all the elements present in our subjects' discourse are related to interaction, communication and collaboration. These three are the keystone of the foundation of any professional community or community in general. Any functional professional community builds on them in order to achieve its goals. Yet, interaction and communication are to be seen as pre-conditions for a consistent and meaningful functioning, so as to achieve the ultimate goal for professional communities working in the educational field: to improve learning outcomes of students and overall teachers' activity. Any community prevailing on the communication/interaction level solely will not succeed in achieving this goal. In the subjects' responses there are, evidently, some missing links.

Within the 'Characteristics' dimension, the first missing aspect is reflective dialogue. Many accounts in our research define professional community with reference to communication, dialogue, freely expressing ideas and opinion, but none makes reference to a reflective dialogue. As Roberts and Pruitt (2003: 7) explain, the reflective dialogue is 'to discuss the teaching practices and collaborate on how they can be improved'. The Romanian teachers mention several goals for dialogue and communication within the professional community (such as solving problems of their dayto-day activity in classroom, receiving advice or debating on common themes), but the reflection on their practice is not one of them. The answers 
suggest the idea of support, but not the idea of communicating for improving practice.

Table 3. Comparing responses in our study with the framework for the professional community (Kruse, Louis and Bryk 1995)

\begin{tabular}{|c|c|c|}
\hline Dimensions & $\begin{array}{l}\text { Framework for the professional } \\
\text { community } \\
\text { (Kruse, Louis, and Bryk 1995) }\end{array}$ & Present study \\
\hline \multirow{5}{*}{ Characteristics } & Shared values and norms & $\begin{array}{l}\text { Shared values and norms* } \\
\text { 'group of people interacting based on } \\
\text { common values' }\end{array}$ \\
\hline & Reflective dialogue & $\begin{array}{l}\text { Reflective dialogue* } \\
\text { 'a group where we can debate on problems } \\
\text { and ideas and where everyone can get a } \\
\text { piece of advice' } \\
\text { 'a group discussing on common themes' }\end{array}$ \\
\hline & Deprivatization of practice & Deprivatization of practice \\
\hline & $\begin{array}{l}\text { Collective focus on student } \\
\text { learning }\end{array}$ & Collective focus on student learning \\
\hline & Collaboration among teachers & $\begin{array}{l}\text { Collaboration among teachers } \\
\text { 'group of professionals collaborating in } \\
\text { everyone's best interest' } \\
\text { 'cooperation for getting help' }\end{array}$ \\
\hline \multirow{5}{*}{$\begin{array}{l}\text { Structural } \\
\text { conditions }\end{array}$} & Time to meet and discuss & $\begin{array}{l}\text { Time to meet and discuss* } \\
\text { 'group of people interacting in order to } \\
\text { exchange information and experiences' } \\
\text { 'group of people overtly discussing on } \\
\text { problems related to work' }\end{array}$ \\
\hline & Physical proximity & $\begin{array}{l}\text { Physical proximity } \\
\text { 'common place for interacting and } \\
\text { exchanging opinions' }\end{array}$ \\
\hline & Interdependent teaching roles & Interdependent teaching roles \\
\hline & Communication structures & $\begin{array}{l}\text { Communication structures* } \\
\text { 'group of people that periodically meet and } \\
\text { communicate' }\end{array}$ \\
\hline & $\begin{array}{l}\text { Teacher empowerment and school } \\
\text { autonomy }\end{array}$ & $\begin{array}{l}\text { Teacher empowerment and school } \\
\text { autonomy }\end{array}$ \\
\hline \multirow[b]{2}{*}{$\begin{array}{l}\text { Human/social } \\
\text { resources }\end{array}$} & Openness to improvement & Openness to improvement \\
\hline & $\begin{array}{l}\text { Skill/cognitive base } \\
\text { Supportive leadership } \\
\text { Socialization }\end{array}$ & $\begin{array}{l}\text { Respect* } \\
\text { 'group with members respecting each other } \\
\text { and respecting rules' } \\
\text { Skill/cognitive base } \\
\text { Supportive leadership } \\
\text { Socialization } \\
\text { 'group of members that socialize both } \\
\text { professionally and extra-professionally' }\end{array}$ \\
\hline
\end{tabular}

Note: Features written in grey are not present at all in the subjects' responses in our study; Features with * are present, but in a changed manner (see explanations in text). 
Other missing features in the teachers discourse are deprivatization of practice and collective focus on student learning. The first one means to open the classroom for other colleagues, in order to observe and eventually learn. Interestingly, this practice exists in the Romanian educational system, but the teachers responding in our study do not mention it, suggesting the idea that 'opening' the classroom for colleagues is not understood as related to the professional community or as a way for strengthening it. The collective focus on student learning means teachers should reflect as a professional group on student learning activities and outcomes, as well as on the methods to improve them. This aspect is also not acknowledged in our sample of teachers and specialists.

Many answers referred to shared values/norms and to collaboration and cooperation among teachers as essential characteristics for the professional community. 'Shared values' represented a frequently used utterance, whereas remarkably few references to 'norms' were made. Generally, the answers just mention collaboration/cooperation and not the purposes or benefits that would emerge from them.

In the dimension regarding the structural conditions, most utterances refer to communication structures and physical proximity, whilst interdependence, empowerment and autonomy are totally missing. Communication structures pertain to the existence of regular channels and means for communication. While the answers relate to the periodicity of meetings, solely the face-to-face communication is mentioned. Perhaps this too explains the reason for the emphasis put on the physical proximity, as a prerequisite for an effective professional community. Also, teachers talk about meeting and discussing but do not refer to the importance of providing an adequate time to interact. Apart from these three, there are two more complex structural conditions, distinctive for a more fulfilling activity: playing the teaching roles in an interdependent manner and empowering teachers and allowing for autonomy in choosing methods and teaching as they think is best for their students. These two are not present in our respondents' answers. They either consider their work to not be in this way, or they fail to mention it.

In the human and resources area, there is no explicit reference to skills or knowledge acquired through participation in the professional 
community, also no reference to openness for improvement and leaders offering support. Socialization is mentioned and also is respect, but there is not one account talking about trust.

Returning to the second core-concept of this research, i.e. sense of community, the results show two dimensions: the 'sense of community' characteristics and actions/behaviours. Many authors analyse both this dimensions in their work (McMillan and Chavis 1986; Beck 1999; Rovai 2002). The last author shows (Beck 1999: 24) that in describing community, not only metaphors delineating intangible features are used, but also metaphors denoting actions and behaviours. In our research, teachers and specialists mentioned the following actions/behaviours relevant for the sense of community: communication/exchange of information, collaboration/cooperation, common action, offering support/advice, discussions about problems and solving them, freely exchanging opinions, implication/participation, sharing experiences and socialization. In the sense of community characteristics category, teachers and specialists bring up cohesion/unity as the basic characteristic and then, with fewer occurrences, interpersonal relations, acceptance/tolerance and availability.

Three additional attributes delineate the complete picture of teachers and specialists in Sibiu kindergartens on professional community: the size, the time and the structural dimensions. There is no agreement regarding how many members a professional community should have. While some answers affirm a professional community should be small, others consider that even large groups can form professional communities. Although few occurrences refer to the time dimension, all agree that a professional community means a 'steady', 'constant' or 'traditional' interaction. The findings are consistent with other authors' results (Noddings 2005: 64). Also a few responses refer to the need to have organised and structured meetings, gatherings, discussions, etc.

\section{Discussion}

The results show intriguing aspects regarding the preschool practitioners' participation in professional groups and their understandings of what a professional community means. 
Good practices characterize the participants in our research. Nearly all of our respondents belong to at least one professional group with intense participation. There is also space for improvement, as participation is mainly confined to institutional borders. In part, this is a good thing; having in mind that Royal, DeAngelis and Rossi (1996) show that community size is a predictor for the sense of community. They show that teachers in small schools have a stronger sense of community than teachers in large schools. Yet, we still believe that membership in larger professional groups/communities would be a progress for teaching activity and learning outcomes. Targeting a bigger population for exchanging ideas and resources, developing new skills, solving problems and offering support would bring more richness and diversity and therefore, more effectiveness in teachers' activity.

Perhaps the most intriguing results of the present research relate to how preschool practitioners view professional community. Recent papers show the way preschool practitioners understand community and sense of community is constitutive for their attitudes towards day-to-day practice and career (McGinty, Justice and Rimm-Kaufman 2008). Taking this as a starting point, we consider of significant importance the findings in the present study.

Furman (2002: 51-52) suggests that communities today are facing a paradox: they are more and more socially diverse, but members are bound to participate based on commonalities, and to comply with specific values and norms. Regarding the commonalities shared by members in a professional community, practitioners in Sibiu kindergartens mention first and foremost 'goals' and 'interests'. Putting this in front (numerous occurrences in answers) and having 'values' and 'skills' at the end of the list (few occurrences) certainly compose a picture of how members understand such a community: the elements brought as a contribution in the community mainly concern motivation and action toward common goals.

Further qualitative exploration of answers reflects professional community as a social space where practitioners can receive support, guiding and counselling. The frequent use of words such as 'support', 'help', 'advice' suggests the strongest need of teachers and implies that their work environment is perceived as problematic and difficult. There are also 
numerous answers considering the communication, collaboration, interaction to be the essential trait of a professional community. While these three elements are organic for any professional community, only few goals for communicating, collaborating and interacting are mentioned: to discuss on common themes, to solve problems related to practice and to get support. Respondents do not refer to issues like learning from each other, gaining new skills for improving activity, or self-reflection on their own practice to gain an insight on its quality.

Taking a step back and having an overall look at answers, they suggest that practitioners in our study use what it is put in common in the professional community mainly for one reason: to get support on specific issues in their practice. They communicate, discuss, debate on issues of common interests but they are not taking a step further - to gain a collective understanding of their practice, its quality and what can be done to be improved. The loop is not closing. The participation in the professional community is not translated into a reflective practice and is not mirrored in enhancing day-to-day activities. The underlying assumption seems to be the understanding of interaction and communication as intrinsic goals, rather than basic conditions for a professional community. For an effective, selfconscious practice, those two have to become tools for achieving more complex outcomes.

In addition, the practitioners' views on professional community point to some other features of their practice: little emphasis on structure, practice not so much open to colleagues and not developed in public ways, limited access to expertise, or lack of supportive leadership. As stated by Kruse, Louis and Bryk (1995: 37), these are key aspects for the professional community.

An essential ingredient is considered important for a functional community (including professional) and it is missing among answers received from practitioners in our study, i.e. trust. Coleman (1990: 188-189) considers trust as a key element characterizing the members of a community. In our study, none of the answers makes reference to trust. Instead, respect is brought up as well as many references to reciprocity and one reference of tolerance. Reciprocity (Putnam 2000) and tolerance (Walzer 1997) are as important as trust in building a strong community. 


\section{Conclusions}

The research aiming to understand professional community was conducted on almost the entire population of teachers and early childhood educational specialists working in kindergartens in Sibiu city. A survey was completed by 308 practitioners. The present paper has presented only a small part of items in the survey, processed both qualitatively and quantitatively. The research questions addressed two main areas: to briefly describe the belonging of practitioners in professional groups/communities and to understand their construct of the professional community concept.

With regard to the first area, results show massive participation in professional groups, but confined to the institutional borders. Belonging to local or national groups/communities is less frequent. Practitioners share the view that professional groups in which they currently belong can be considered communities. A high satisfaction rate with these groups' overall activity is present.

In the second area, the qualitative inquiry has shown a rather basic approach of what a professional community should be: a place for interacting and communicating in order to get support when needed, but in a less extent a place for self-reflection on practices or a place for identifying areas for enhancement. Practitioners speak about professional community in terms of respect and reciprocity and less in terms of trust and tolerance.

Several implications for practice can be drawn. Preschool practitioners should continue the effort to be part of groups and communities in their work area, but some improvements should be aimed: to increase the structure of the interaction by making it more regular and with more focused agendas; to extend membership beyond the borders of the institution and to target mostly the national and international collaborations (the last ones are almost entirely missing); to reflect on practice, tools, skills, outcomes in order to improve them; to find ways to open and share the individual practice to colleagues. 


\section{Acknowledgement:}

The data analysed in this paper was collected as part of the Leonardo da Vinci international partnership project Play and Learning in the Early Years for Inclusion (2009-2011), project no. LLP-LdV/PAR/2009/RO/010, Lifelong Learning Programme, funded by the European Commission through the National Agency for Community Programmes in the Field of Education and Professional Training (ANPCDEFP).

\section{References:}

Baranowska, Wanda, Gill McGillivray and Adela Popa. 2011. Play and Learning in the Early Years for Inclusion. Working in an international context. Birmingham: Newman University College.

Beck, Lynn G. 1999. Metaphors of Educational Community: An Analysis of the Images That Reflect and Influence Scholarship and Practice. Educational Administration Quarterly 35 (1): 13-45.

Bourgeault, Ivy Lynn, Cecilia Benoit and Kristine Hirschkorn. 2009. Introduction: Comparative Perspectives on Professional Groups Current Issues and Critical Debates. Current Sociology 57 (4): 475-485.

Cohen, Anthony Paul. 1985. The Symbolic Construction of Community. London: Routledge.

Coleman, James C. 1990. Foundations of Social Theory. Cambridge: Harvard University Press.

Dawson, Shane. 2006. A Study of the Relationship between Student Communication Interaction and Sense of Community. Internet and Higher Education 9 (3): 153-162.

Evetts, Julia. 2006. Short Note: The Sociology of Professional Groups New Directions. Current Sociology 54 (1): 133-143.

Ferrari, Joseph R., Shaun E. Cowman, Lauren A. Milner, Robert E. Gutierrez and Peter A. Drake. 2009. Impact of School Sense of Community Within a Faith-based University: Administrative and Academic Staff Perceptions on Institutional Mission and Values. Social Psychology of Education 12 (4): 515-528.

Furman, Gail C. 2002. Postmodernism and community in schools. Unraveling the paradox. In School as Community: From Promise to Practice, ed. Gail Furman, 51-77. Albany: State of New York University Press.

Graves, Liana N. 1992. Cooperative learning communities: Context for a new vision of education and society. Journal of Education 174 (2): 57-79.

Guo, Ying, Joan N. Kaderavek, Shayne B. Piasta, Laura M. Justice and Anita McGinty. 2011. Preschool Teachers' Sense of Community, Instructional Quality, and Children's Language and Literacy Gains. Early Education E Development 22 (2): 206-233. 
Kruger, Louis J., Sharone L. Maital, Gayle Macklem, David Shriberg, Donna M. Burgess and Rachel Kalinsky. 2001. Sense of community among school psychologists on an internet site. Professional PsychologyResearch and Practice 32 (6): 642-649.

Kruse, Sharon, D., Karen Louis and Anthony Bryk. 1995. An emerging framework for analysing school-based professional community. In Professionalism and Community: perspectives on Reforming Urban Schools, eds. Karen Louis and Sharon Kruse, 23-45. Thousand Oaks: Corwin Press.

Levine Laufgraben, Jodi and Nancy Shapiro. 2004. Sustaining and Improving Learning Communities. San Francisco: John Wiley and Sons.

Lomos, Catalina, Roelande H. Hofman and Roel J. Bosker. 2011. Professional communities and student achievement - a meta-analysis. School Effectiveness and School Improvement 22 (2): 121-148.

McGinty, Anita S., Laura Justice and Sara E. Rimm-Kaufman. 2008. Sense of School Community for Preschool Teachers Serving At-Risk Children. Early Education \& Development 19 (2): 361-384.

McMillan, David W. and David M. Chavis. 1986. Sense of Community: A Definition and Theory. Journal of Community Psychology 14 (1): 6-23.

Popa, Adela. 2011. Practicieni din educația preşcolară despre incluziune şi joc. O cercetare calitativă în trei țări europene. In Repere pentru construirea unei radiografii sociale a lumii contemporane, eds. Dorel Morândău and Dumitru Batâr. Sibiu: Editura Universității Lucian Blaga din Sibiu.

Noddings, Nel. 2005. The Challenge To Care In Schools: An Alternative Approach To Education. New York: Teachers College Press.

Putnam, Robert. 2000. Bowling Alone. The collapse and revival of American community. New York: Simon \& Schuster.

Roberts, Sylvia M. and Eunice Z. Pruitt. 2003. Schools as Professional Learning Communities: Collaborative Activities and Strategies for Professional Development. Thousand Oaks: Corwin Press.

Rovai, Alfred P. 2002. Building Sense of Community at a Distance. The International Review of Research in Open and Distance Learning 3 (1), http://www.irrodl.org/index.php/irrodl/article/view/79/152.

Royal, Mark, Karen DeAngelis and Robert Rossi. 1996. Teachers' sense of community: How do public and private schools compare? Washington DC: American Institutes for Research in the Behavioral Sciences and the National Center for Education Statistics. http://nces.ed.gov/pubs/97910.pdf

Visscher, Adrie and Bob Witziers. 2004. Subject departments as professional communities? British Educational Research Journal 30 (6): 785-800.

Walker, Michael, Stanley Wasserman and Barry Wellman. 1994. Statistical models for social support networks. In Advances in Social Network 
Analysis, eds. Stanley Wasserman and Joseph Galaskiewicz, 53-78. Thousand Oaks: Sage Publications, Inc.

Walzer, Michael. 1997. On Toleration. New Haven: Yale University Press.

Wellman, Barry and Milena Gulia. 1999. The network basis of social support: A network is more than the sum of its ties. In Networks in the Global Village, ed. Barry Wellman, 83-118. Boulder: Westview Press.

Westheimer, Joel and Joseph Kahne. 1993. Building School Communities: An Experience-Based Model. Phi Delta Kappan 75 (4): 324.

Wighting, Mervyn J. 2006. Effects of Computer Use on High School Students' Sense of Community. The Journal of Educational Research 99 (6): 371-380. 